Saudi Journal of Medical and Pharmaceutical Sciences

Abbreviated Key Title: Saudi J Med Pharm Sci

ISSN 2413-4929 (Print) |ISSN 2413-4910 (Online)

Scholars Middle East Publishers, Dubai, United Arab Emirates

Journal homepage: https://saudijournals.com/sjmps

Original Research Article

\title{
Acute and Sub-Acute Toxicity Effect of the Ethanol Leaf Extract of Justicia Insularis in Wistar Rats
}

\author{
Akuodor Godwin Christian ${ }^{1 *}$, Okorie Anthonia Ugochi ${ }^{2}$, Ekenjoku John Azubuike ${ }^{3}$, Megwas Anthony Uchenna ${ }^{4}$, Aja \\ Daniel Ogbonna John², Irogbeyi Longinus Amarachi ${ }^{3}$, Okezie Ogwuegbu Alozie ${ }^{5}$ \\ ${ }^{1}$ Department of Pharmacology and Therapeutics, Faculty of Medicine, College of Health Sciences, Nnamdi Azikiwe University, Nnewi Campus, \\ Nigeria \\ ${ }^{2}$ Department of Pharmacology and Therapeutics, Faculty of Medicine, Ebonyi State University, Abakaliki, Nigeria \\ ${ }^{3}$ Department of Pharmacology and Therapeutics, Abia State University, Uturu, Nigeria \\ ${ }^{4}$ Department of Optometry, School of Health Technology, Federal University of Technology, Owerri, Nigeria \\ ${ }^{5}$ Department of Chemical Pathology, Federal Teaching Hospital, Abakaliki, Nigeria
}

DOI: $10.36348 /$ sjmps.2020.v06i02.014 | Received: 11.01.2020 | Accepted: 18.01.2020 | Published: 28.022020

*Corresponding author: Dr. Akuodor Godwin C

Abstract

Justicia insularis leaves widely used in African traditional medicine for the management of malaria, pains, diabetes, convulsion and bacterial infections was screened for its acute and sub-acute effects in Wistar rats. In acute toxic test, the leaf extract was orally administered to rats up to $5 \mathrm{~g} / \mathrm{kg}$ in different doses. This was followed by observing the animals for signs of toxicity and mortality for 7 day. In sub-acute toxicity study, the rats were orally treated daily with $J$. insularis ethanol extract at doses of $200 \mathrm{mg} / \mathrm{kg}, 400 \mathrm{mg} / \mathrm{kg}$ and $600 \mathrm{mg} / \mathrm{kg}$ for 21 days. The rats used for control were given distilled water. All animals were weighed at 7 day intervals all through the study and the haematological, biochemical parameters and vital organs were all determined, at the end of the study. J. insularis ethanol leaf extract was practically non-toxic showing no mortality and visible signs of toxicity on acute exposure. The extract showed significant increase in the body weight of rats given $400 \mathrm{mg} / \mathrm{kg}$ and $600 \mathrm{mg} / \mathrm{kg}$ compared to control. The leaf extract showed significant increase in haematological indices, but there was no alteration in biochemical indices, and the vital organs as well. Findings in this study revealed that $J$. insularis was safe when orally administered, while we suggest further investigation to ascertain its effect on long-term administration.

Keywords: Justicia insularis, Ethanol leaf extract, Safety assessment, Wistar rats. Implication for health policy/practice/research/medical education.

Copyright @ 2020: This is an open-access article distributed under the terms of the Creative Commons Attribution license which permits unrestricted use, distribution, and reproduction in any medium for non-commercial use (NonCommercial, or CC-BY-NC) provided the original author and source are credited.

\section{INTRODUCTION}

In recent years, herbs have been proven to be of high importance for prevention and treatment of different diseases and of high value to immunological provocation against much pathologic conditions [1]. In herbal medicine, several plants have been used to treat and prevent diseases. Many of these plant extracts boost humoral cell mediating immunity against bacteria, virus, fungi, protozoa, cancer and even haematological parameters [2].

The widely acceptability of herbal medicines has actually been limited probably due to dearth of defined chemical characterization, dose regimen and adequate toxicity data to determine their safety [3]. The indiscriminate increase in the use of plant extract is further aggravated by the fact that herb are safe simply because they are natural in origin. Bioactives derived from plant acts as defense mechanism but at the same time can be toxic in nature which may not compensate the therapeutic index. Many plants are regarded as toxic due to the presence of some nonliving inclusions and the presence of these substances causes irritations and stomach upset.

Justicia insularis, which belong to the family Acanthaceae, is an herbaceous and perennial plant 30$75 \mathrm{~cm}$ high with opposite ascending branches. Its leaves are simple, opposite, and the flower white, pink or purple. It can be found in variety of habitats from moist forest to dry savannah region. You can find it in cultivated land, refuse heaps, grasslands and forest edges. It requires humus-rich, fertile soil for optimum growth, but can succeed in sandy or loamy soil. It propagates in the wild, the seed remains dormant during dry season, germinating with the return of the rain. 
Justicia insularis is cultivated in home gardens in west and central African, especially in Guinea, Sierra Leone, Ghana, Togo, Benin, Nigeria, Cameroon and DR Congo [4]. It is a traditional vegetable in Benin, [5]. Akwa Ibom people in South South, Nigeria uses the leaves to cook soup and they call it Isepe-akera. The therapeutic effect and ailment treated with Justicia insularis in Southern and Western part of Nigeria include digestion, laxative and as weaning agent. Studies undertaken by [6] revealed the presence of alkaloids flavonoids and glycoside in the leaves. In Senegal, the leaf decoction of $J$ insularis is given to women during last month of pregnancy to reduce labour pain. In the western region Cameroon, it is used in association with the leaves of three other medicinal plant (Aloe buettneri, Hibiscus macranthus, and Dicliptera verticillata), to treat dysmenorrhoea and some cases of women infertility. This aqueous extract mixture has also been proven, in a series of studies to induce ovarian steroidogenesis and folliculogenesis in female rats [7].

The aim of this study was to investigate the safety activity of the leaf extract of Justicia insularis by evaluating its haematological and biochemical effects in Wistar rats.

\section{Materials ANd Methods Plant Material Collection}

Fresh leaves of Justicia insularis were collected in the month of July, 2018 from Iguelaiho village of Ova south west local government of Edo state, Nigeria. The leaves were identified and authenticated by a taxonomist in Herbarium unit of Department of Botany, University of Nigeria, Nsukka.

\section{Plant Extraction}

The fresh leaves were rinsed thoroughly in distilled water and air-dried in the Laboratory of the Department of Pharmacology and Therapeutics, Ebonyi State University, Abakaliki until a constant weight was maintained. The dried plant material was ground to fine powder and soaked in absolute ethanol (600 $\mathrm{g}$ in $2.5 \mathrm{~L})$ with constant agitation. The extract was filtered $48 \mathrm{~h}$ later. The filtrate was evaporated to dryness using water bath at a reduced pressure, giving a greenish semi-solid with a yield of $8.5 \%(\mathrm{w} / \mathrm{w})$. The dried extract was stored in a refrigerator at $4^{0} \mathrm{C}$ and later reconstituted in distilled water before administration to experimental animals.

\footnotetext{
Animals Used in the Study

Male Wistar rats (200-250 g) used for this study were purchased from animal house unit, Enugu, Nigeria. The animals were acclimatized for at least 14 days. Six rats were housed per cage and were maintained in a well-ventilated animal room with temperature of $25-27{ }^{0} \mathrm{C}$ and 12-h light/dark cycle. The animals had free access to rodent pellet and portable water ad libitum. The cage beddings and water bottles
}

were cleaned on a daily basis. Animals were handled according to the International Guidelines Care and Handling of Experimental Animals [8].

\section{Phytochemical Analysis}

Phytochemical screening of the leaf extract of Justicia insularis was carried out for various secondary metabolites such as alkaloid, carbohydrates, saponins, tannins, flavonoids, terpenoids, steroids, glycosides, phenol, resins and reducing sugar using standard method $[9,10]$.

\section{Acute Toxicity Study (Oral Route Using Gavage Intubation)}

Oral acute toxicity test was performed using the Organization of Economic Cooperation and Development (OECD) guideline for testing of chemicals 401 [11]. Male rats weighing 180-200 g were used for this study, and were conducted in two phases. Three groups of 3 rats in each cage were administered 100,600 and $1000 \mathrm{mg} / \mathrm{kg}$ of the leaf extract orally. They were observed for signs of toxicity and mortality for 24 hours with special attention given to the first $4 \mathrm{hrs}$. This was followed by administration of the extract $(2000,3000$ and $5000 \mathrm{mg} / \mathrm{kg}$ ) to the next three groups of 3 rats and equally observed as earlier stated, and daily for 7 days for any signs of toxicity which include salivation, paw-licking, writhing, change in body weight and mortality. The number of deaths in each group was recorded and the final $\mathrm{LD}_{50}$ values were calculated.

\section{Sub-Acute Toxicity Study}

A total of twenty-four rats were weighed and divided into 4 groups of 6 male and 6 female rats in each cage for the study. Six rats were grouped based on three different treatment doses of the leaf extract with one control (distilled water) group. The rats were orally treated daily with $J$. insularis leaf extract at doses of $200 \mathrm{mg} / \mathrm{kg}, 400 \mathrm{mg} / \mathrm{kg}$ and $600 \mathrm{mg} / \mathrm{kg}$, and distilled water for 21 days [12]. All rats were individually weighed immediately before dosing on day 1 and once a week throughout the study. All animals were observed daily for mortality, general condition, and clinical signs before the test and throughout the dosing period. Clinical observations, including motor activity, appearance, and central and autonomic functions, were performed daily.

\section{Relative Organ Weight Measurement}

On day 21, rats were fasted overnight but had free access to drinking water for 24 hours before being sacrificed under inhaled chloroform anaesthesia. Different organs namely the heart, kidneys, liver, spleen and lungs were surgically dissected out, weighed and macroscopically examined (absolute organ weight). The relative organ weight (ROW) of each harvested organ was calculated as: 


Absolute organ weight $(\mathrm{g})$
Body weight of animal on sacrifice day $(\mathrm{g})$

\section{Haematological Measurements}

Blood samples analyzed (automated haematology analyzer; Mythic 18 by Orphee, Switzerland) included the following: pack cell volume (PCV), red blood cell (RBC) count, Hemoglobin concentration (HB), platelet count (PLT), white blood cell (WBC) count, mean corpuscular volume (MCV), mean corpuscular haemoglobin $(\mathrm{MCH})$, mean corpuscular haemoglobin concentration (MCHC).

\section{Biochemical Analysis}

The serum concentrations of alkaline phosphatase (ALP), alanine transaminase (ALT), aspartate transaminase (AST), albumin (Alb) urea $(\mathrm{Bu})$, creatinine (Crea), total cholesterol (TC), triglycerides (TGs) and high density lipoprotein (HDL) cholesterol were determined using (Gesan Chem 200, USA) automated analyzer.

\section{Statistical Analysis}

The data were analyzed using SPSS version 26.0. Data are expressed as mean \pm SEM. One-way analysis of variance (ANOVA) and post hoc Tukey's test were used to identify differences among the groups. $P$ value $<0.05$ was considered significant.

\section{RESULTS AND DiSCUSSION}

\section{Phytochemical Analysis}

The phytochemical screen of the ethanol leaf extract of Justicia insularis contains the following secondary metabolites; alkaloid, saponins, tannins, flavonoids, terpenoids, steroids, glycosides, phenol, resins and reducing sugar.

\section{Acute Oral Toxicity}

The leaf extract of $J$. insularis at all the tested dosages produced no mortality in rats at 24, 48 and 72 hours after administration. There was no observed signs of toxicity such as behavior patterns, nature of stool and salivation in all experimental rats, even at the highest dosage of $5000 \mathrm{mg} / \mathrm{kg}$. This result clearly confirms that $J$. insularis ethanol leaf extract do not produce oral toxicity at the doses tested. The oral $\mathrm{LD}_{50}$ value of the plant was $5000 \mathrm{mg} / \mathrm{kg}$ body weight.

\section{Effect of the Leaf Extract on Body Weight}

Table-1 showed the leaf extract compared to the control, caused significant increase in the percentage body weight in a dose dependent manner with the highest increase recorded at the doses of 400 and $600 \mathrm{mg} / \mathrm{kg}$ in the 21 day treatment period.

\section{Effect of the leaf extract on haematological parameters}

The effects of sub-acute administration of $J$. insularis leaf extract on haematological parameters is presented in Table-2. All haematological parameters assayed (packed cells volume, red blood cells, platelet count, mean corpuscular volume, mean cell haemoglobin, mean cell haemoglobin concentrate, haemoglobin, white blood cells, platelet, neutrophils, lymphocytes and monocytes) in extract treated rats were not significantly different when compared to the control group.

\section{Effect of the leaf extract on biochemical parameters}

Table- 3 shows the value of serum biochemical parameters after treatment period of 21 days. There were no significant difference in liver function parameters (aspartate transaminase, alanine transaminase and alkaline phosphatase) observed in rats after treatment. The leaf extract produced no significant changes in albumin, total cholesterol and high density level cholesterol as well as plasma Triglycerides after 21 day treatment period.

\section{Effect of the leaf extract on serum electrolytes, urea and creatinine}

Justicia insularis ethanol leaf extract did not produce significant effect on the serum electrolytes, sodium, potassium, chloride and bicarbonate after 21 day daily administration. Furthermore, the extract did not show significant change in urea in treated animals compared to the control (Table-4).

\section{Effect of the leaf extract on organ weight}

There were no significant difference in the weight of the organs between the control and the extract treated rats (Table-5).

Table-1: Effect of $J$. insularis leaf extract on body weight of Wistar rats in sub-acute study

\begin{tabular}{|c|c|}
\hline Dose $(\mathbf{m g} / \mathbf{k g})$ & Percentage weight change \\
\hline Control & $26.30 \pm 1.44$ \\
\hline 200 & $29.12 \pm 2.57$ \\
\hline 400 & $31.44 \pm 3.20$ \\
\hline 600 & $34.62 \pm 2.42$ \\
\hline \multicolumn{2}{|c|}{ Results are presented as Mean \pm SEM $(\mathrm{n}=6)$}
\end{tabular}


Akuodor Godwin Christian et al; Saudi J Med Pharm Sci, Feb., 2020; 6(2): 225-231

Table-2: Effects of Justicia insularis ethanol leaf extract on haematological parameters in Wistar rats

\begin{tabular}{|c|c|c|c|c|}
\hline Parameters & Control & $\mathbf{2 0 0}$ & $\mathbf{4 0 0}$ & $\mathbf{6 0 0}$ \\
\hline & 1 & 2 & 3 & 4 \\
\hline $\mathrm{WBC}\left(\mathrm{x} 10^{9} / \mathrm{L}\right)$ & $7.50 \pm 1.44$ & $7.95 \pm 2.89$ & $8.65 \pm 3.65$ & $9.87 \pm 2.54$ \\
\hline $\mathrm{RBC}\left(\mathrm{x} 10^{12} / \mathrm{L}\right)$ & $7.36 \pm 0.19$ & $8.90 \pm 0.27$ & $9.77 \pm 2.12$ & $9.87 \pm 2.36$ \\
\hline $\mathrm{Hb}(\mathrm{g} / \mathrm{dL})$ & $12.90 \pm 1.37$ & $14.45 \pm 1.66$ & $14.50 \pm 0.99$ & $15.03 \pm 0.38$ \\
\hline $\mathrm{PCV}((\%))$ & $48.74 \pm 0.68$ & $46.50 \pm 2.10$ & $51.74 \pm 1.10$ & $54.57 \pm 1.16$ \\
\hline Platelet $\left(\times 10^{9} / \mathrm{L}\right)$ & $230.60 \pm 4.40$ & $260.50 \pm 5.24$ & $340.40 \pm 5.50$ & $365 \pm 6.19$ \\
\hline $\mathrm{MCV}(\mathrm{fl})$ & $58.50 \pm 1.84$ & $61.13 \pm 2.24$ & $54.44 \pm 9.03$ & $61.80 \pm 2.22$ \\
\hline $\mathrm{MCH}(\mathrm{pg})$ & $18.80 \pm 0.81$ & $18.95 \pm 0.70$ & $18.92 \pm 0.61$ & $19.00 \pm 0.47$ \\
\hline MCHC $(\mathrm{g} / \mathrm{dL})$ & $46.16 \pm 0.47$ & $48.03 \pm 0.16$ & $47.42 \pm 4.32$ & $55.90 \pm 0.36$ \\
\hline Neutrophils $(\%)$ & $2.56 \pm 1.64$ & $3.50 \pm 2.50$ & $3.60 \pm 2.55$ & $3.65 \pm 3.63$ \\
\hline Monocyte $(\%)$ & $0.01 \pm 0.4$ & $0.03 \pm .07$ & $0.04 \pm 0.7$ & $0.04 \pm 0.08$ \\
\hline Lymphocyte $(\%)$ & $6.57 \pm 0.45$ & $6.72 \pm 0.44$ & $8.55 \pm 0.13 *$ & $8.67 \pm 0.35 *$ \\
\hline
\end{tabular}

Values are presented as Mean \pm SEM $(n=6) ;{ }^{*} \mathrm{p}<0.05$ When compared to the control group.

Table-3: Effect of Justicia insularis ethanol leaf extract on serum biochemical parameters in Wistar rats

\begin{tabular}{|c|c|c|c|c|}
\hline \multicolumn{7}{|c|}{ Dose $(\mathbf{m g} / \mathbf{k g})$} \\
\hline Parameters & Control & $\mathbf{2 0 0}$ & $\mathbf{4 0 0}$ & $\mathbf{6 0 0}$ \\
\hline Aspartate transaminase (U/L & $52.50 \pm 0.4$ & $55.70 \pm 0.5$ & $58.50 \pm 0.4$ & $61.45 \pm 0.5$ \\
\hline Alanine transaminase (U/L) & $19.10 \pm 0.3$ & $21.30 \pm 0.5$ & $21.90 \pm 0.3$ & $23.20 \pm 0.4$ \\
\hline Alkaline phosphatase (U/L) & $86.50 \pm 0.4$ & $90.20 \pm 0.6$ & $91.60 \pm 0.4$ & $89.70 \pm 0.3$ \\
\hline Albumine (mg/dL) & $3.90 \pm 0.2$ & $4.10 \pm 0.3$ & $4.10 \pm 0.2$ & $4.30 \pm 0.1$ \\
\hline Total cholesterol (mg/dL & $95.50 \pm 0.6$ & $102.90 \pm 2.1$ & $108.00 \pm 0.4$ & $105.60 \pm 0.3$ \\
\hline Triglycerides (mg/dL) & $35.10 \pm 0.2$ & $35.70 \pm 1.3$ & $37.40 \pm 1.2$ & $37.60 \pm 2.2$ \\
\hline HDL Cholesterol (mg/dL) & $30.70 \pm 1.3$ & $33.50 \pm 0.5$ & $32.80 \pm 0.2$ & $32.90 \pm 1.2$ \\
\hline
\end{tabular}

Values are presented as Mean $\pm \operatorname{SEM}(\mathrm{n}=6) ;{ }^{*} \mathrm{p}<0.05$ when compared to the control group.

Table-4: Effect of Justicia insularis ethanol leaf extract on serum electrolytes, urea and creatinine in Wistar rats

\begin{tabular}{|c|c|c|c|c|}
\hline \multicolumn{5}{|c|}{ Dose (mg/kg) } \\
\hline Parameters & Control & $\mathbf{2 0 0}$ & $\mathbf{4 0 0}$ & $\mathbf{6 0 0}$ \\
\hline $\mathrm{Na}^{+}$ & $141.80 \pm 0.4$ & $143.40 \pm 0.5$ & $145.00 \pm 0.2$ & $145.00 \pm 0.3$ \\
\hline $\mathrm{K}^{+}$ & $5.10 \pm 0.1$ & $5.30 \pm 2.2$ & $5.60 \pm 1.1$ & $5.50 \pm 1.3$ \\
\hline $\mathrm{Cl}^{-}$ & $98.60 \pm 1.4$ & $100.20 \pm 0.3$ & $99.60 \pm 0.5$ & $100.50 \pm 0.3$ \\
\hline $\mathrm{HCO}_{3^{-}}$ & $24.70 \pm 0.3$ & $25.00 \pm 0.4$ & $26.20 \pm 0.1$ & $25.60 \pm 0.4$ \\
\hline Urea & $16.60 \pm 0.2$ & $16.90 \pm 0.5$ & $18.60 \pm 0.2$ & $18.90 \pm 0.3$ \\
\hline Creatinine & $0.30 \pm 0.2$ & $0.30 \pm 0.2$ & $0.60 \pm 0.3$ & $0.60 \pm 0.5$ \\
\hline
\end{tabular}

Results are presented as Mean \pm SEM $(n=6) ;{ }^{*} \mathrm{p}<0.05$ when compared to the control group.

Table-5: Effect of Justicia insularis ethanol leaf extract on rat relative organ weights

\begin{tabular}{|c|c|c|c|c|}
\hline \multicolumn{5}{|c|}{ Dose (mg/kg) } \\
\hline Organs (g) & Control & $\mathbf{2 0 0}$ & $\mathbf{4 0 0}$ & $\mathbf{6 0 0}$ \\
\hline Heart & $0.62 \pm 0.04$ & $0.56 \pm 0.04$ & $0.51 \pm 0.02$ & $0.63 \pm 0.08$ \\
\hline Lungs & $0.89 \pm 0.06$ & $0.92 \pm 0.10$ & $0.95 \pm 0.09$ & $0.97 \pm 0.08$ \\
\hline Kidneys & $0.80 \pm 0.10$ & $0.89 \pm 0.12$ & $0.93 \pm 0.11$ & $0.92 \pm 0.15$ \\
\hline Liver & $4.08 \pm 0.25$ & $4.10 \pm 0.16$ & $4.25 \pm 0.13$ & $4.45 \pm 0.23$ \\
\hline Spleen & $0.73 \pm 0.07$ & $0.82 \pm 0.17$ & $0.79 \pm 0.04$ & $0.85 \pm 0.06$ \\
\hline
\end{tabular}

Results are presented as Mean $\pm \operatorname{SEM}(\mathrm{n}=6) ;{ }^{*} \mathrm{p}<0.05$ compared to the control group

Medicinal plants often possess numerous active pharmacological properties and such has been the basis for the treatment of different diseases [13]. Photochemical constituents of Justicia insularis ethanol leaf extract showed the presence of alkaloids, saponins, tannins, flavonoids, terpenoids, steroids, glycosides, phenols, resins and reducing sugar. As observed, this plant contains biological compounds with potentials to produce beneficial or adverse effects. Therefore, a comprehensive toxicity study is necessary to ascertain its safety. The purpose of investigating the safety of any herbal agent is to identify the nature and importance of detrimental effects, also to know the exposure level where the activity is observed [14]. Some of the risks which may be associated with the application of herbal agents can be made known through toxicity testing [15, 16]. The absence of visible side effect or lethality in rats treated with $5000 \mathrm{mg} / \mathrm{kg}$ dose of the ethanol leaf extract 
of $J$. insularis proved that the extract is practically nontoxic after an acute exposure. The high safety profile obtained may have been responsible for its wide spread use in different ethno-therapeutic interventions. The results further revealed that the extract caused an increase in the body weight of rats in the test groups, compared to the rats in the control group throughout the 21-day period of administration especially the groups that received $400 \mathrm{mg} / \mathrm{kg}$ and $600 \mathrm{mg} / \mathrm{kg}$ of the extract. The implication of this finding could be that the extract contained some nutrients that have the potential to increase body weight.

Different haematological parameters investigated in this study can be used to determine the level of toxic effects of plant extracts in both man and animals [17]. The test can as well be used to determine blood relating activities of plant products [18]. More so, such analysis is important to risk evaluation as changes in the haematological system have higher predictive values for human toxicity when data are translated from animal studies [19].

These conditions can be ruled out in this case as changes (toxic) in haematological parameters (packed cells volume, red blood cells, mean corpuscular volume, mean cell haemoglobin, mean cell haemoglobin concentrate, haemoglobin) were not observed after 21 days administration of $J$. insularis leaf extract in rats. The non-significant effect of the extract on these parameters did not affect erythropoesis and morphology of the red blood cells [20]. White blood cells are the first line of defense responders to pathogenic agents and other inflammatory processes. Furthermore, no significant changes were observed in neutrophils, lymphocytes and monocytes, which also confirmed our findings.

The biochemical analysis were evaluated for possible alterations in liver and kidney functions influenced by this leaf extract. Hepatic and renal function examination is very essential in the toxicity analysis of drugs and plant products as they are both important for the survival of an organism [21]. The ethanol leaf extract of $J$. insularis showed a nonesignificant changes in all biochemical parameters of rats in the 21 day treatment period. Measurement of albumen can represent nutritional status which may be used to test for and assist in the diagnosis of liver and kidney diseases $[22,23]$. The non-significant change in serum albumen observed in the study may suggest potential hepatoprotective effect of $J$. insularis leaf extract. Changes in the level of total cholesterol triglycerides and high density lipoprotein cholesterol can give important information on lipid metabolism and predisposition of the heart to atherosclerosis and other cardiovascular diseases [12]. The data obtained showed non-significant increase in total cholesterol and high density lipoprotein cholesterol parameters, but a significant increase in triglycerides parameter of the treated rats. Determination of serum electrolytes, sodium, potassium chloride, bicarbonate, urea and creatinine parameters are essential markers of kidney function and increase in the levels of these parameters are indicative of kidney infection [24-26]. The leaf extract caused no significant changes in the serum electrolytes in the treated compared to control rats.

Generally, decrease in internal weight of an organ is an indication of toxicity due to exposure to toxic agents [27-29]. There were no significant changes in organ weight relative to the control in the 21 days treatment period. The weight of the lung is less important in toxicity studies probably due to its low frequency of finding weight changes that correlate with toxicity and it is less sensitive predict toxicity compared to histopathology $[30,31]$. However, since the weight of the organs for toxicity were not significantly altered, it could be said that the leaf extract does not produce toxic effect on the vital organs of the treated compared to control rats in this study.

\section{CONCLUSION}

The findings from this study provide useful data on the acute and sub-acute toxicological investigation of $J$. insularis leaf extract. The plant has been shown from the results obtained to be safe on acute and sub-acute oral administration. The observed results showed potential for boosting components of the immune system and protecting the cardiovascular, kidney and liver systems. However, further studies are needed on the leaf extract effects in long term use.

\section{ACKNOWLEDGMENTS}

The authors are grateful to Mr. Simon Eze Nwibo and Chibueze Nwonu of Department of Pharmacology and Therapeutics, Ebonyi State University, Abakaliki, for their technical assistance.

Conflict of Interest: The authors have no conflict of interest in conducting this study.

\section{Ethical Consideration}

All processes involved in the handling of animals and the experiment was carried out according to the standard protocols approved by the Animal Ethics Committee of the Faculty of Medicine Ebonyi State University, Abakaliki, Nigeria, (EBSU/DRIC/UREC/04/053/18).

\section{REFERENCES}

1. Sharma, G. N., Dubey, S. K., Sharma, P., \& Sati, N. (2011). Medicinal values of bael (Aegle marmelos)(L.) Corr.: A review. Int J Curr Pharm Rev Res, 2(1), 12-22. 
2. Malwal, M., \& Sarin, R. (2011). Antimicrobial efficacy of Murraya koenigii (Linn.) Spreng. root extracts. Indian Journal Nat Prod Resour. 2(1):4851.

3. Gautam, M. K., \& Goel, R. K. (2014). Toxicological study of Ocimum sanctum Linn leaves: hematological, biochemical, and histopathological studies. Journal of toxicology, 2014;1-10

4. Burkill, H. M. (1985). The useful plants of west tropical Africa $2^{\text {nd }}$ Ed. Vol. 1, royal Botanic Garden K. E.W. 960.

5. Achigan-Dako, E. G., Avohou, H. T., Ahouanmagnagahou, R. A., Vodouhe, R. S., \& Ahanchede, A. (2009). Viability response of cucurbit seeds (Citrullus lanatus subsp. mucosospermus, Cucumeropsis mannii and Lagenaria siceraria) stored under various moisture content and temperature conditions. Seed Science and Technology, 37(2), 520-526.

6. Telefo, P. B., Moundipa, P. F., \& Tchouanguep, F. M. (2004). Inductive effect of the leaf mixture extract of Aloe buettneri, Justicia insularis, Dicliptera verticillata and Hibiscus macranthus on in vitro production of estradiol. Journal of ethnopharmacology, 91(2-3), 225-230.

7. Telefo, P., Moundipa, P. F., Tchana, A. N., Tchouanguep, C., \& Dzickolze-Mbiapo, F. T. (1998). Effect of d'Aloe buettneri, Justicia insularis, Hibiscus marcranthus and Dicliptera vercillata on some physiological and biochemical parameters of reproduction in immature female rats. Journal Ethno pharmacol. 63:193-200.

8. NIH. (2011). Guide for the Care and Use of Laboratory Animals. 8th ed. Bethesda MD: National Institutes of Health. 82-83

9. Aziz, M. A. (2015). Qualitative phytochemical screening and evaluation of anti-inflammatory, analgesic and antipyretic activities of Microcos paniculata barks and fruits. Journal of Integrative Medicine, 13(3), 173-184.

10. Billmary, C., Janne, R., Luccro, M., \& Maria, C. (2015). Preliminary Phytochemical Screening of Pirmenta racemosa Var. racemose (myrtaceae) from Tachira-venezula. Pharmacol online. 1:121125.

11. Organisation for Economic Cooperation and Development. (2008). OECD Guideline for Testing of Chemicals (TG 407). Acute Oral Toxicity-Fixed Dose Procedure. OECD/OEDC.

12. Ibrahim, M. B., Sowemimo, A. A., Sofidiya, M. O., Badmos, K. B., Fageyinbo, M. S., Abdulkareem, F. B., \& Odukoya, O. A. (2016). Sub-acute and chronic toxicity profiles of Markhamia tomentosa ethanolic leaf extract in rats. Journal of ethnopharmacology, 193, 68-75.

13. Wang, L., Li, Z., Li, L., Li, Y., Yu, M., Zhou, Y., ... \& Xu, Y. (2014). Acute and sub-chronic oral toxicity profiles of the aqueous extract of Cortex
Dictamni in mice and rats. Journal of ethnopharmacology, 158, 207-215.

14. Ezeokpo, B. C., Akuodor, G. C., Erejuwa, O. O., Akpan, J. L., Nnolim, B. I., Eze, C. O., Nwobodo, M. U., \& Ezeonu, C. T. (2019). Sub-Chronic oral toxicity study of Pseudocedrela Kotschyi ethanol leaf extract in wistar rats. Saudi Journal Pharm and Medical Science. 5(9):769-774.

15. Obidike, I., \& Salawu, O. (2013). Screening of herbal medicines for potential Toxicities: Pharmacology. Toxicology and Pharmaceutical Science: New insight in Toxicology and Drug Testing: Pub. InTech, Chapter 4. 63-67.

16. Santos, S. R., Rangel, E. T., Lima, J. C. S., Silva R. M., Lopes, L., Noldin, V. F., ... \& Martins, D. T. O. (2009). Toxicological and phytochemical studies of Aspidosperma subincanum Mart. stem bark (Guatambu). Die Pharmazie-An International Journal of Pharmaceutical Sciences, 64(12), 836839.

17. Sunmonu, T. O., \& Oloyede, O. B. (2010). Performance and haematological indices in rats exposed to monocrotophos contamination. Human \& experimental toxicology, 29(10), 845-850.

18. Obidike, I. C., Idris-Usman, M. S., John-Africa, L. B., \& Salawu, O. A. (2011). An Evaluation of Acute and Sub Chronic Toxicological Effects of Hymenocardia acida Leaf Extract in Adult Wistar Rats. Journal of Pharmacology and Toxicology, 6(4), 400-408.

19. Agbaje, E. O., Adeneye, A. A., \& Daramola, A. O. (2009). Biochemical and toxicological studies of aqueous extract of Syzigium aromaticum (L.) Merr. \& Perry (Myrtaceae) in rodents. African Journal of Traditional, Complementary and Alternative Medicines, 6(3):241-254.

20. Yakubu, M. T., Akanji, M. A., \& Oladiji, A. T. (2007). Hematological evaluation in male albino rats following chronic administration of aqueous extract of Fadogia agrestis stem. Pharmacognosy Magazine, 3(9), 34-38.

21. Olson, H., Betton, G., Robinson, D., Thomas, K., Monro, A., Kolaja, G., ... \& Dorato, M. (2000). Concordance of the toxicity of pharmaceuticals in humans and in animals. Regulatory Toxicology and Pharmacology, 32(1), 56-67.

22. Guyton, A. C., \& Hall, J. E. (2006). Texbook of Medical Physiology, Sauder, Philadelphia, USA. 1152.

23. Olorunnisola, O. S., Bradley, G., \& Afolayan, A. J. (2012). Acute and sub-chronic toxicity studies of methanolic extract of Tulbaghia violacea rhizomes in Wistar rats. African Journal of Biotechnology, 11(83), 14934-14940.

24. Thierry, T. A., Acha, A. E., Paulin, N., Aphrodite, C., Pierre, K., \& Tazoacha, A. (2011). Subacute toxicity study of the aqueous extract from Acanthus montanus. Electronic J Biol, 7(1), 1115 . 
25. Saad, B., Azaizeh, H., Abu-Hijleh, G., \& Said, O. (2006). Safety of traditional Arab herbal medicine. Evidence-Based Complementary and Alternative Medicine, 3(4), 433-439.

26. Gowda, S., Desai, P. B., Kulkarni, S. S., Hull, V. V., Math, A. A., \& Vernekar, S. N. (2010). Markers of renal function tests. North American journal of medical sciences, 2(4), 170-173.

27. Patrick-Iwuanyanwu, K. C., Amadi, U., Charles, I. A., \& Ayalogu, E. O. (2012). Evaluation of acute and sub-chronic oral toxicity study of baker cleaners Bitters- a poly-herbal drug on experimental rats. EXCLI. 11:632-640.

28. Akindele, A. J., Adeneye, A. A., Salau, O. S., Sofidiya, M. O., \& Benebo, A. S. (2014). Dose and time-dependent sub-chronic toxicity study of hydroethanolic leaf extract of Flabellaria paniculata Cav. (Malpighiaceae) in rodents. Frontiers in pharmacology, 5, 78.
29. OA, A. S., TM, E. H., \& AA, A. M. (2002). Effect of prolonged vigabatrin treatment on hematological and biochemical parameters in plasma, liver and kidney of Swiss albino mice. Scientia Pharmaceutica, 70(2), 135-145.

30. Michael, B., Yano, B., Sellers, R. S., Perry, R., Morton, D., Roome, N., ... \& Schafer, K. (2007). Evaluation of organ weights for rodent and nonrodent toxicity studies: a review of regulatory guidelines and a survey of current practices. Toxicologic pathology, 35(5), 742-750.

31. Amna, O. F., Nooraain, H., Noriham, A., Azizah, A. H., \& Husna, R. N. (2013). Acute and oral subacute toxicity study of ethanolic extract of Cosmos caudatus leaf in Sprague Dawley rats. International Journal of Bioscience, Biochemistry and Bioinformatics, 3(4), 301-305. 